\title{
The agency of the Holy Spirit and heuristic categories for discernment in spirituality
}

\begin{abstract}
Living in a complex world with many challenges may render discernment as Christian spiritual practice increasingly important. If discernment is understood as an interpretation of the movement of the Holy Spirit in life, one obvious and fruitful avenue to gain better insight into this may entail an exploration of the very nature of this agency. To map the work of the Spirit is a striking hiatus in scholarly literature on discernment, and the article intends to address this. The need is for heuristic, that is, problem-solving, categories for reflecting on the agency of the Spirit. This article specifically contributes towards exploring such insight by studying contemporary developments in pneumatology. In recent study on the work of the Spirit, seven trends are investigated, and corresponding notions such as novelty, emergence, justice, hospitality, beauty, the impossible, and relationality emerge as ways to interpret the movement of the Spirit. These motifs, it is argued, may provide a lens to discover the divine possibilities in each moment in life and to understand discernment better.
\end{abstract}

\section{INTRODUCTION: DISCERNMENT \& PNEUMATOLOGY}

"A discernment of cries". This lies at the core of a wise and creative theology for the twenty-first century, asserts Ford (2011:1) in a reflection on the future of Christian theology. Discernment is an imperative in our time; there is an urgent need for both a critical reading of the deep changes and shifts taking place globally and a courageous naming of what responsible living might entail. At stake, for Christians and theology, is more than Aristotelian phronēsis, practical wisdom, which is often mentioned by philosophers.1 Christian discernment is about distinguishing the divine possibilities at each moment. 2 The active presence of God in the world is fundamental to a Christian vision; events do not merely occur. Discernment in Christian spirituality has a basic Trinitarian grammar (Lonsdale 2005a:247).3 The work of the triune God should be perceived and interpreted under and in the conditions of our time. Discernment, however, is not a simple human reflex; it requires a sensitive antenna to the mysterious movement of the divine, rendering it a most demanding practice. The focus of this article is on one specific aspect of these "divine possibilities", of this grammar of discernment - the pneumatological. The work of the Spirit or, in other words, pneumatic agency will be examined. The thesis to be explored is that attention to the nature of the work of the Holy Spirit may contribute to

1 Prominent, e.g., in works by Gadamer, Ricoeur and MacIntyre.

2 The Dutch scholar of spirituality, Kees Waaijman, writes extensively about the diakrisis (2000:481-

512), and identifies a basic insight (2000:508): "Onderscheiding ziet in de feitelijkheid de goddelijke ontwikkelingsmogelijkheden die zich ieder moment aanbieden."

3 In another contribution, Lonsdale (2005b:248) strikingly describes discernment in terms of pneumatology: "It is an attempt to help persons and communities to tune in to what the Spirit of Christ is doing and desires to do in the world." 
a better understanding of discernment. Put another way, adequate categories for describing pneumatic agency may have heuristic potential for discernment. If a lens is available to perceive the work of the Spirit, such an undertaking has, in my opinion, not been adequately addressed in related literature.4 Sustained attention to the character of the work of the Spirit in discussion on Christian discernment has been neglected.

The wider frame for the problem to be addressed is the relationship between doctrinal theology and spirituality, which does not enjoy consensus in scholarship and which cannot be explored in this instance. 5 Suffice it to say that my approach is dialogical, accepting that Systematic Theology could be enriched and determined by spirituality and experience, but simultaneously suggesting a hermeneutical function for doctrinal articulations. This implies that dogmatic explorations may provide a spatial sphere, a symbolic or linguistic world for interpreting and even stimulating experiences. 6 Dogmatic statements are interpretations in language, which creates, as sociology of knowledge taught us, 'worlds' which are inhabited and which generate subsequently various experiences. This will be embodied in the approach of this article. A brief overview will be given of the state of scholarship on pneumatology, and main developments and emphases will be introduced without any claim to exhaustive treatment. An attempt will be made to distil major motifs prominent in contemporary thinking about the Holy Spirit.

The aim of the article and of the specific approach serves this hermeneutical orientation. By identifying these so-called contemporary motifs, I intend to construe categories for reflecting on and addressing intellectual questions. Put differently, in the words central to the long traditions of discernment, criteria will be named to discern various spirits of our time. Potentially three contributions could be made: an idiom to speak about the Holy Spirit under the intellectual conditions of our time may be suggested; a hermeneutical lens for reading events and texts spiritually may be provided, and discernment as such may be relocated to a broader, public sphere. Delimitation should also be mentioned. "The juncture of mind and Spirit", which is central in discernment and which has been thoroughly explored by Munzinger (2007) in his study, ${ }^{7}$ is not the question to be addressed in this instance. The article has a specific theological focus, that is, the nature of God the Spirit's work.

\section{TRENDS IN CONTEMPORARY PNEUMATOLOGY - CENTRAL MOTIFS}

4 Reference to the Holy Spirit is often found, but an explicit exploration of the nature of the work of the Spirit is neglected in discussions of discernment. One example may illustrate this. In her recent work on discernment, Liebert (2008) describes it as "the process of becoming aware of how God is present, active and calling us ..." (:8); it is "the desire to follow the Spirit of Jesus" (:9). She emphasises that it "does matter how we think about God" (:15), and identifies in her seven-step procedure for discerning a decision that one should seek the "presence of indicators", that is "signs of the Holy Spirit's work" (:20). However, nowhere in her study is the very nature of God's work through the Spirit theorised. In the more detailed discussion of the practice of discernment, she refers to the work by Jonathan Edwards (:151), but offers no theological reflection of her own.

5 For a brief, but good discussion, see Endean (2005:74-79).

6 Interestingly, in his discussion of discernment, Buckley (1993:274) warns that religious experience does not absolve one from critical reflection and the doctrinal content of Christian faith.

7 Munzinger's (2007:18) study argues for discernment as the "nerve centre" of Pauline thinking. Developing a comprehensive approach to discernment, he links spirituality, ethics and theology in Paul. Discernment is about the "interaction of human mediation and divine revelation", and the result of the eschatological new heart. Despite his thorough and detailed scholarship on discernment, and his intended comprehensiveness, I have a lingering concern that an inadequate pneumatology is the weakness of the work. My impression is that a privatised notion of the Spirit's work is found in the subtext of the argument. 
The position of pneumatology remains ambivalent in recent Systematic Theology. In some work, the reduction to Christology and soteriology continues, with a concomitant narrow privatised vision of the Christian faith; fortunately, there are clear indications of new sensibilities. One example can be highlighted: the volume Constructive Theology (see Jones \& Lakeland 2005) with contributions by a number of scholars in the USA known for their progressive intuitions. ${ }^{8}$ The chapter on pneumatology not only warns about new "sites of Spirit-talk" (e.g., feminism and charismatic renewal), but also offers an intriguing "subaltern history" of the Spirit, presenting a historical account from the underside. Constructive proposals along cosmic, ecological and musical (jazz) keys are presented. The creative nature of the exploration matches the very free nature of the Spirit. Of particular interest in the extended chapter is a mapping exercise, suggesting avenues for discerning the Spirit; these are "six marks of the Spirit's movement" (2005:243ff), indicating that the Spirit is prophetic, performative, particular, processual, paradoxical and primordial. This article intends to do something similar, but with a different approach. This section will identify a number of critical developments in pneumatology and one major motif will be distilled accompanying each one. It is emphatically not an essentialising exercise, but merely an endeavour to listen to voices, and to learn how the Spirit's work is conceptualised in various intellectual spheres. The basic conviction is that these newer trends may allow glimpses into the nature of the Spirit's agency.

\subsection{Holy Spirit and Pentecostalism - Novelty}

The obvious phenomenon to highlight from the outset is arguably global Pentecostalism. From the perspective of a sociology of religion, considering the rapid global growth of the movement and the large numbers at stake, this is a most significant development in the history of the Christian faith. This elicits a host of questions which are beyond the scope of this article. Excellent treatments are available which discuss the origin, development, internal mutations, and various features of the theological edifice. ${ }^{9}$ Suffice it to state that the movement signals a larger social shift - a resistance to both the tyrannies of tradition and modernity. The astute observer Harvey Cox (1999:139) is of the opinion that we are witnessing "a fascinating transformation of religion, a creative series of self-adaptations" to the momentous change taking place in society, a barometer to something larger whose inner meaning is still being gauged. The question is whether an outstanding motif could be gleaned from the movement in order to generate new insight into the work of the Spirit.

Conventional treatments usually point to the same recurring themes. Kärkkäinen (2002:92), for example, names a particular brand of spirituality as the core of Pentecostalism and the category experience as being essential to it. The doctrine of Spirit baptism is regarded as the single most important element of the Pentecostal pneumatology, which is affirmed by speaking in tongues (2002:95ff). Apart from these generic structural features, motifs such as power and healing are often encountered. In certain contexts, for instance in Africa, additional themes such as prosperity and spiritual warfare, have also acquired prominence.

It is important to note that a rather vibrant and ambitious Pentecostal scholarship, probing beyond mere description of the phenomenon, has been emerging. Some of the most creative and constructive reflection on pneumatology is undertaken by Pentecostal theologians. The

8 The textbook by Plantinga et al. (2010) should also be mentioned. The chapter on pneumatology is indicative of a new awareness, and the Spirit is related to newer Trinitarian developments, but also to the appreciation of a cosmic orientation, i.e. ecology, world religions, and holistic spirituality.

9 The work An introduction to Pentecostalism (2004) by the leading authority Allan Anderson is recommended. See also Anderson, Bergunder, Droogers \& Van der Laan (2010) for an outstanding multidisciplinary study on the phenomenon of Pentecostalism. 
work by Amos Yong, to mention only one scholar, extensively explores crucial and pressing contemporary problems such as faith and science, inter-religious dialogue, politics, human disability, and global theology from a Pentecostal perspective. His theology goes beyond narrow denominational concerns and contributes to a deepening of pneumatology as such. Traditional theology cannot afford to ignore the research done by Pentecostal scholars.

Another influential Pentecostal scholar, James Smith (see 2003:109ff), may pave the way to identify a critical motif indicative of the identity of this movement. He raises the question of the fundamental elements of a Pentecostal world view and identifies radical openness to God and, more specifically, God doing something differently or new as central to this movement. His scriptural appeal is to Acts 2 where Peter offered a pneumatic explanation of the strange phenomena. God is working in unexpected ways because of the continued ministry of the Spirit. ${ }^{10}$ Smith's (see, e.g., 2008) deeper philosophical convictions emerge in other work. Intrinsic to Pentecostalism is a specific ontology - a dynamic, open and participatory one. Being as such is not closed, but open to the surprises of God. Smith resists metaphysical and methodological naturalism, which presupposes a closed universe with no possibility of novelty. ${ }^{11}$

\subsection{Holy Spirit and Science - Emergence}

One of the most significant and exciting discourses in theology is represented by the faith-science dialogue. The incorporation of pneumatological perspectives in this reflection holds the promise of generating potentially fruitful avenues for the entire theological enterprise. The groundbreaking work of Pannenberg (see esp. 1994:79-84) in this regard should be mentioned. ${ }^{12} \mathrm{He}$ incorporated terminology from physics such as force-field in his treatment of the Holy Spirit. A complex of notions such as cosmic Spirit, life, materiality and body can be associated with this more recent interest and warrant detailed expositions of each one of these. This article will focus on one specific central theme in the faith-science conversation - that of divine agency. An active participant in this debate, Philip Clayton (2005:345), is of the opinion that the question of divine agency represents science's single greatest challenge to theology. The importance of this issue is understandable and is also reflected in the ambitious twenty-year interdisciplinary project on Scientific perspectives on divine action..$^{13}$ To reflect pneumatologically on divine agency as central problem in the faith-science question may open truly interesting avenues.

The very possibility of divine action seems in a quantum era much less problematic than in a previous cosmological dispensation presupposing naturalistic closure. Polkinghorne

10 The other elements Smith identifies include healing of the body, the role of experience and an affective epistemology, and commitment to empowerment and social justice.

11 What surfaces in this instance is the intriguing contribution of Pentecostal scholars to the faith-science debate, especially concerning divine agency. Smith counters an interventionist model of divine action. The Holy Spirit is always at work in creation; sometimes, however, the "intensity of participation" may change (see 2008:890). Such a view allows for regularity and the miraculous. For further and a more detailed discussion on Spirit and Philosophy, and Spirit and Science, see two recently published works by outstanding Pentecostal scholars: Smith (2010), and Smith and Yong (2010).

12 Several concerns inform Pannenberg's pneumatology. He tries to avoid the dangers of privatising the Spirit to subjective areas, and to counter the reduction of the Spirit's work to soteriology. Hence, his starting point is a retrieval of the Biblical notion of the Spirit as the life-force sustaining all life. Employing Michael Faraday's ideas, he aligns theology with the changed view of physics on the relation between force and body, i.e. bodies are regarded as forms of forces. See Kärkkäinen (2004a) for a full discussion of Pannenberg's views, as well as for the wider application of his pneumatology, especially to his doctrine of God. He also offers some critical remarks.

13 This was jointly undertaken by the Vatican Observatory and the Berkeley Centre for Theology and the Natural Sciences. See Russell et al. (2008) for summaries of the research. The neglect of pneumatological exploration is one of the disturbing weaknesses of this most commendable project. 
(2006:169ff), who is both theologian and particle physicist, argues for room for the spiritual dimension by appealing to both the "intrinsic unpredictabilities in the physical process" and the "self-effacing character" of the Spirit's presence. By interfacing Heisenberg's uncertainty principle of quantum physics and the theological tradition of the reticent, veiled or hidden work of the Spirit, opens the possibility of speaking of God's work in the creaturely realm. True novelty can emerge in this instance. ${ }^{14}$

The argument for this possibility intimates a critical issue for pneumatology, the question of a cosmological framework. The question can be raised as to whether the paradigm shift in physics from Newton to Einstein has been adequately registered in theology and especially pneumatology. In a seminal article, Vondey (see 2009) attempted to profile the repercussions of these two cosmologies for pneumatology. In line with Pannenberg's thesis, he points to the replacement of the concept of force by field theory, but also that time and space are no longer external to matter, but are intrinsic to it. According to Vondey (see 2009:27-36), pneumatology should be developed in terms of an entirely different set of notions such as order, rationality, relationality and movement, for example. The role of the Spirit as agent of order ${ }^{15}$ and rationality in the cosmos should be thought afresh. Particularly suggestive is his proposal that the Spirit should be revisioned in a new cosmology valuing process and change, not as presence, but as movement. ${ }^{16}$

One problem of utmost importance has crystallised in the debate on causality: the emergence of complexity. The key question is whether higher levels of reality in the hierarchy of complexity are simply the outcome of lower level casual powers, or whether bottom-up causation should be complemented by top-down notions. George Ellis (2006:759) mentions the "casually incomplete theory of the world" of physics, because questions pertaining to ethics, aesthetics, metaphysics and meaning lie beyond the ambit of science. "Nature's stunning capacity for selfcomplexification" (Gregersen 2006:782) has afforded theologians the opportunity to counter reductionist views of science and to connect concepts of emergence and complexity with divine action. The work of Amos Yong (see 2006) deserves careful notice. ${ }^{17} \mathrm{He}$ is well aware that emergence is a metaphysical construct and, as a theologian, he links emergence explicitly with the Holy Spirit. The processes of differentiation in reality are ascribed to the life-giving presence and activity of the Spirit of God (2006:198). A pneumatological account of emergence is an attempt to account for the openness of the world to its future. ${ }^{18}$

14 Russell's (see, e.g., 2007:202ff) notion of NIODA (non-interventionist objective divine action) has become well known in faith-science circles. He expressly locates God's action at quantum level. Whether he has developed this pneumatologically is not known to me.

15 Vondey (2009:28) observes that the Spirit is responsible not only for order and harmony, but also for disorder, chaos and discontinuity. In his early work on pneumatology, the Dutch scholar, Van de Beek (1987:210-214), presents a treatment of "de chaotiserende Geest". These insights are based on the work by another Dutch theologian, Van Ruler.

16 It should be pointed out that Vondey's important work is in a sense one-sided. The story of paradigm shift in physics and eventually cosmology entails not only the work by Einstein on general and special relativity, but also the constellation of developments concerning quantum mechanics by scholars such as Bohr and Heisenberg. To situate pneumatology in the faith-science debate is daunting and requires an acquaintance with cosmological developments since the second half of the twentieth century.

17 These few remarks cannot do justice to Yong's detailed and nuanced arguments. His major work The Spirit of creation (2011) should be consulted. In this book, he engages with the Divine Action Project from a Pentecostal perspective and develops a detailed pneumatological cosmology.

18 The new work edited by Welker (2012) on the cosmic work of the Spirit is relevant to the discussion in this entire section. This book signals the growing importance of the intersection between pneumatology, ecology and faith-science discussions. 


\subsection{Holy Spirit and Politics - Justice}

Pneumatology has not escaped the powerful deprivatising trend in theology with the articulation of various liberation theologies since the 1960s. The Holy Spirit has been linked with social conflict and the liberative aspirations of people subjected to multiple forms of injustice. Various proposals are currently available as academic resources which can stimulate reflection on the work of the Holy Spirit in a political key. One of the earlier book-length explorations was the Latin American José Comblin's The Holy Spirit and Liberation (1989). This work not only attended to the experiences of the Spirit in history by the poor in their quest for liberation, but explicitly addressed the need for a new model of spirituality (1989:125-139), expressing life in the Spirit "in the midst of the real world, with its economic and social structures, its politics". In this instance, a pneumatology is developed of the Spirit's action in and through history, which is observed in the irruption of the poor. Recently, Amos Yong surprised with his In the days of Caesar (2010) - an impressive and comprehensive Pentecostal political theology. His so-called "Pentecostal assist" is an attempt to make a genuine creative contribution to a field already crowded with proposals. His basic hypothesis is conveyed in the motto "many tongues, many political practices" (2010:109) and his Biblical appeal is mainly - in typical Pentecostal manner - to Luke-Acts. This complex and multilayered work addresses a wide range of spheres, namely politics, economics, culture and history. However, the argument is so dense that the reader finds it difficult to seek a unified pneumatological entry into the work. The central notion of justice is sadly neglected.

One can obviously argue in a variety of ways about the Biblical evidence for a relation between Spirit and justice. One striking example can be singled out: the pairing of Spirit and justice by the eighth-century Judean prophet Micah (see Levison 2009:41-47 for a fitting discussion). In his indictment of other prophets, Micah is surprised by their ignorance of justice (3:1 - "Should you not know justice?"). The question about the Spirit "being cut short" (2:7, i.e. losing patience) is countered with an appeal to justice: as long as there is justice, the Spirit is not cut short. In the confrontation with the other, false, prophets, Micah construes his own prophetic identity in terms of Spirit, power and justice - "But as for me, I am filled with power, with the Spirit of the Lord, and with justice and might" (3:8). Two fundamental realities are linked in this instance: the axiomatic quality of justice (see also 6:8) and the endowment of the prophet with the Spirit of the Lord.

Michael Welker's work (1994) is a major text on pneumatology, and is important not only for his methodology, but also for the themes he discusses which are particularly relevant to this article. He rejects abstract treatments of the Spirit, and focuses as systematic theologian on the Biblical witnesses and on the broad spectrum of experiences of God's Spirit. A clear sensitivity to the socio-political work of the Spirit can be detected throughout his work. The experiences of the Spirit are "firmly embedded in various experiences of life that is threatened and endangered ... A people is threatened with annihilation. A political system collapses ..." (1994:x). The triad "justice, mercy, and knowledge of God" runs like a golden thread through the work (see, e.g., 1994:221 as major statement to this effect). The Book of Judges and the messianic passages in Isaiah receive thorough interpretation. Liberation signifies distinct signs of the work of the Spirit. The presence of the Spirit is discerned as "a renewal of the people's power of resistance in the midst of universal despair" (Welker 1994:53). He repeatedly asserts that the Spirit is the "Spirit of righteousness". A number of other views by Welker are noteworthy: the Spirit champions diversity and plurality (1994:134) and works in creaturely "fleshliness" (1994:163); the Spirit is a "public person" (1994:312) as it forms the domain of Christ's resonance. ${ }^{19}$.

19 Like Pannenberg, Welker (see 1994:313 esp. n 51) utilises a non-theological term - "domain of resonance" - borrowed from Luhmann. This refers to the fact that identity is formed in a network of 


\subsection{Holy Spirit and Religions - Hospitality}

The relation of the Christian Faith to other religions, and the question of the status of those religions form some of the most difficult intellectual challenges for theology. An exclusivist model is obviously possible, as it is also encountered in fundamentalist circles. Increasingly, an ethically more accountable approach frames the problem as being faithful to one's own truthseeking tradition, whilst respecting and even valuing other similar traditions. A wide range of inclusivist and pluralist proposals are available, without any of these having acquired normative status. Noteworthy, however, is the enthusiasm for probing Trinitarian options in the discourse. ${ }^{20}$ Apart from these suggestions, one also encounters explicit pneumatological endeavours which deserve attention, and which will be briefly introduced in this section.

The work by Haight (2008) exemplifies such a typical pneumatological attempt to come to terms with religious plurality. The objective, in this instance, is not to present his work as necessarily the most persuasive, but to investigate the kind of rhetoric employed by proponents of such an approach. He is convinced that a theology of the Spirit may be the key to a satisfying Christian theology of religions. His argument consists of a number of crucial theological moves. Spirit is viewed as a symbol with a specific referent, that is, the transcendent, creative and salvific power at work in the world (2008:63). He avoids personal language, and is most sensitive to the non-literal quality of all speech about God. Intentionally, Haight defines Spirit with an expansive intent. This is also evident in the representation of the relation between Christ and the Spirit by opting for a Spirit-Christology. The Spirit is viewed as preceding Christ; this implies that His entire ministry was constituted by the Spirit. This obviously weakens the focus on the absoluteness of the Christ figure. Finally, Haight re-envisions the conceptual framework for understanding the divine-world/human economy (2008:65ff). He replaces the traditional chronological twophase scheme of salvation, which follows creation, with an evolutionary model which fashions creation and salvation in a more integrated manner. This allows God as Spirit to act in the world as power and love in a comprehensive sense, also in religions where responses to ultimacy are manifested. His model is an unavoidable shift from Christocentrism to Theocentrism. Haight's proposal, which has been presented in a truncated manner, gives an indication not only of the theological arguments present in this approach, but also of the stark problems inherent in the entire challenge of religious pluralism.

Amos Yong formulated a "pneumatological theology of inter-religious hospitality" which should be meticulously studied. ${ }^{21}$ Like Haight, he stresses that our specific historical moment post-9/11, according to him - renders exclusivist claims problematic and requires more dialogical approaches. In typical Pentecostal fashion, he finds the starting point in Acts 2:17, with the narrative of the Holy Spirit being poured out on all flesh and which speaks of God's universal embrace of humanity with her many cultures, languages and religions (2007:58ff). Luke-Acts is primarily a witness of Trinitarian hospitality (2008:100ff). Christian hospitality is grounded in the hospitable God - "God gives himself by the Holy Spirit at Pentecost to all flesh, and by doing so welcomes and embraces all of humanity" (2007:62). Pentecost is an ultimate expression and manifestation of divine hospitality. Christian faith, according to Yong, should be performed, meaning that God's hospitality should be embodied in a hospitable church. Finally, hospitality requires reciprocity and mutuality. Interestingly, this elicits some of the implications of Yong's dialogical model: an inter-religious encounter can change Christians as such! This may be the

relationships. The presence of the Spirit can be felt in worldwide influence and effectiveness (1994:315).

20 The work by Kärkkäinen Trinity and religious pluralism (2004b) offers an exceptionally good overview of the major proposals in this regard.

21 Yong has published widely on this. Hospitality and the Other (2008) conveys his views in detail. The 2007 article summarises his major arguments quite succinctly. 
surprises which the Spirit could bring. Hospitality should especially be performed at the table; eating with the religious Other may establish authentic dialogue. His dialogical approach of interreligious hospitality is more ambiguous than other models, because it requires discernment in each context and to what the Spirit may be saying and requiring (Yong 2007:65). He is confident that the Spirit may be active in various religions in surprising ways (Yong 2007:65).

The emphasis on hospitality and its express relation to the Spirit is a valuable insight. Hospitality has become a major optic in both postmodern theory and Christian theology. An appreciation of the pluralistic context of contemporary society and of the major challenges generated by Otherness and the perennial possibility of violence chiefly contributed to this re-appreciation of an ancient virtue. Literature on the topic abounds, also in theology. ${ }^{22}$ Yong's specific contribution is to link Otherness Biblically with the Lucan writings, define it pneumatologically and apply it to a major intellectual problem.

\subsection{Holy Spirit and Aesthetics - Beauty}

The growing interest in another conversation, namely that between theology and arts, ${ }^{23}$ should not escape our attention in the search for heuristic categories to speak about the agency of the Spirit. Notions such as beauty, wonder, and enjoyment emerge in this instance; these have been sadly neglected in the past and resulted in impoverished discourse about God. Theological aesthetics have become a potentially productive resource for exploring ways to speak about the work of the Spirit. Despite the new interest in linking God with beauty, explicit pneumatological treatment remains a field to be developed more fully. In this brief purview, possible avenues for such further reflection can be mentioned.

The remarkable Biblical narrative in Exodus 35:30ff, recounting the endowment of Bezalel and Oholiab with artistic skill by God's Spirit to construct the tabernacle, forms an obvious starting point. Striking in this passage is the association of creativity with the work of the Spirit. ${ }^{24}$

In the Christian tradition, one occasionally encounters, for instance in Irenaeus, Clement of Alexandria, and the Cappadocians, some connotation of beauty with the Spirit. In the West, the association of beauty has been predominantly with the Son, for example in the work of Augustine, Thomas and even Von Balthasar. According to Sherry (2007:8), the more explicit pneumatological discussions of beauty are found in the work of Russian theologians such as Evdomikov and Bulgakov, and especially in the work of the eighteenth-century American Puritan Jonathan Edwards. Beauty is arguably more pervasive in his work than in any other theologian's (see Farley 2001:43). Brief remarks can be made about the role of the Holy Spirit in his aesthetics. His consistent Trinitarian theology forms the background of Edwards's thought; the role of the Spirit in the Triune life determines his understanding of pneumatic beauty. In typical eighteenthcentury fashion, beauty is equated with harmony: the Spirit is the harmony, the excellence and the beauty of the deity (see Delattre 2006:152ff). As substantial love, the Spirit is divine beauty. Edwards also identifies the Spirit with joy, delight, happiness and affection. Authentic religious experience, as "sense of the heart" - to employ typical terminology by Edwards - is an actual infusion of the One who is beauty, and is consequently "an aesthetic experience of the deepest kind" (see Mitchell 2003:28).

The most detailed contemporary exposition of the relation between the Holy Spirit and

22 One major recent source can be mentioned, that by Newlands and Smith - Hospitable God (2010).

This work examines hospitality as a cognitive tool for reframing thinking about God, divine action and discipleship, and explores the application to urgent social dilemmas. Unfortunately, a pneumatological perspective on hospitality has been neglected.

23 For an overview, see Dyrness (2007).

24 For a detailed discussion, see the article by Hess (2011). 
aesthetics is found in the work by Sherry - Spirit and Beauty (2002). His basic argument is developed in terms of Trinitarian theology and eschatology. The Spirit's work is to communicate in natural and artistic beauty the glory of the Father. Earthly beauty is an anticipation of the transfigured world to come. He ponders the implications of a neglect of beauty as category to understand God and the Christian life. Appreciating beauty contributes to a renewal of the doctrine of God and to a retrieval of fundamental human responses such as wonder, joy and celebration (see 2002:164-173; 2007:13).

\subsection{Holy Spirit and Postmodernity - The Impossible}

The so-called "turn to religion" is one of the remarkable developments in the intellectual horizon since the last quarter of the twentieth century. One specific trajectory of this interest, which manifested itself in various academic fields, is relevant to this article: the interaction with Heidegger's notion of onto-theology and with Derrida's later thought. Major works on God by philosophers of religion such as Marion (1991), Kearney (2001) and Caputo (2006) have been published. These works established a discourse with clearly recognisable features, and are of significance to theology. Kearney's term anatheism captures the central concern aptly: a return to God after the atheist critique of the traditional God of onto-theology. This is an attempt to present "a divinity at last free from the three-headed monster of metaphysics - the Omni-God of omnipotence, omniscience, and omnipresence ..." (Manoussakis 2006:xvi). A new set of terms has emerged - gift, hospitality, otherness, and excess - to reflect on transcendence and the divine. ${ }^{25}$ One particular central category plays a major role in the debate and will be briefly introduced: the Impossible. Unfortunately, the potential application to and significance for pneumatology have not yet been - to my knowledge - investigated. The semantic connotations to the term convey critically important insights which can be used to reflect on the agency of the Holy Spirit. Such an argumentative move will not only assist pneumatology, but also place it within the ambit of postmodern sensibilities.

One specific exposition by a Christian theologian can be conveyed in this instance. David Tracy (2011:124), a talented scholar and active participant in this discourse, appreciates the Impossible as a most productive entry to the question of naming God in our postmodern era: "this postmodern route of the Impossible ... is an exceptionally promising route to naming God as the incomprehensible, hidden, all-loving one whom we worship." The background to this notion is the radical critique of the self-confidence of the modern logos, the ambition to understand the reality of God, to fit God into a specific horizon of intelligibility. ${ }^{26}$ The quotation of Tracy's view conveys the three senses he identifies to fill the Impossible with content: incomprehensibility, hiddenness and love (see 2011:124-127). The Impossible God is radically beyond our grasp; is veiled in suffering and negativity, and is sheer excess and gift. This notion of God disrupts and transgresses our modernistic rationality, our power relations and our understanding of love.

Tracy's interpretation of the Impossible is acutely relevant to a reflection on the identity and the agency of the Spirit. Traditionally, the Spirit has been associated exactly with these descriptors. The question about doing theology after onto-theology presents itself with urgency. Schrijvers $(2006: 303,313)$ correctly points out that the critique of onto-theology carries with

25 The series of conferences at Villanova University, resulting in a number of important volumes, should be mentioned. See, e.g., the one that highlights the notion of "the Impossible" - Caputo \& Scanlon (1999) God, the gift and postmodernism.

26 Onto-theology decides in advance how God will enter philosophical discourse. Most often God is modelled after causal theories, and God becomes the prima causa, the First Being. God cannot be anything else but the totality of being, saving beings from contingency and incoherence. See Schrijvers (2006:302ff). 
it the seed of idolatry-critique. Theology should be aware of her perennial tendency to master transcendence. The challenge can be framed differently: the otherness of the Other should be respected. Thinking and speaking about the Other should be on the Other's terms, and not a reduction of the Other to a reflection of the same. The postmodern discourse and the contributions by thinkers such as Marion, Kearney and Caputo and their respective proposals about "saturated phenomena", "excess of posse beyond esse" and about "God as event", provide valuable resources to overcome onto-theology, and to disrupt attempts to control God conceptually, including the Holy Spirit.

\subsection{Holy Spirit and Trinitarian Renaissance - Relationality}

At some stage, an academic treatment of the Holy Spirit's work is confronted to address fundamental questions, which are less impressionistic and more ontological. At least three such questions can be identified. Is it possible to integrate in some manner the diverse testimonies and experiences encountered in Christian Scripture to construct some minimally identifiable profile of the Spirit? What is the relationship between the two testaments and their distinct representations of the Spirit; ${ }^{27}$ is there a continuity? Finally, what is the relative position of the Spirit to YHWH and to Jesus Christ? These questions amount to a basic, but central problem: the ultimate mystery of the identity of the Spirit. ${ }^{28}$ Two resources may assist in addressing this and will be cursorily introduced in this section: the Trinitarian Renaissance, and the turn to relationality.

The question concerning the identity of the Spirit was historically never subjected to the same intense scrutiny and debate as that of Jesus Christ. Constantinople ("the Lord, the giver of life ... who together with Father and Son is worshipped and glorified") stabilised the identity of the Spirit, and for the Western tradition Augustine's description of the Spirit as the bond of love (vinculum caritatis) became immensely influential. The filioque controversy resulted in two divergent pneumatologies in the East and the West. The critical insight is that the Spirit has always been conceptualised in terms of referentiality (see, e.g., Welker 2007:243, 245), albeit with different emphases by the two great Christian traditions. That the Spirit is eternally related to the Father from whom procession takes place, and that the Spirit witnesses to the Son who had sent her resulted in an ambiguous biography of the Spirit. There is at once a recognisable identity, but at the same time some element of reduction and even eclipse. The Spirit can be understood in terms of the Father and the Son and their mutual relationship, but here remains an intriguing elusiveness, a certain veiledness.

Recent Bibliological studies have stressed the complex and variegated nature of the OT traditions of the Spirit of God (see Firth \& Wegner 2011), and the genealogy of traditions from Israel via Judaism to Early Christianity (see Levison 2009). Ontological continuity is finally not a matter of argumentation, but of faith conviction. Levison, who has produced arguably the most important Bibliological work in recent years, argues strongly for continuity, and may represent

27 The associations of Spirit in the OT and NT are emphatically diverse. The OT has a more cosmic orientation, and endowment is selective; the NT has a virtual exclusive focus on Jesus Christ, and a universal character, but within a limited and specific social sphere - the church. See, e.g., Schweizer (1989:408ff).

28 See Webster's (1983:4) comment on the need to identify the Spirit. 
an emerging majority position. ${ }^{29}$ The Trinitarian Renaissance of the late twentieth century ${ }^{30}$ has not only "recovered" the doctrine of the Trinity as central mystery of the Christian faith, but also established a new appreciation of the relational nature of the very identity of the Christian God. This new interest has stimulated the re-examination of traditional theological positions, and advocated a consistent re-visioning of the entire edifice of systematic theology. Consequently, pneumatology is also being revisited.

One such project is that by Jürgen Moltmann (1992) with his notion of a Trinitarian pneumatology. He is dismissive of the reductionist tradition of limiting the Spirit to the church and the mediation of grace, and of opposing revelation and experience as exclusive alternatives. Creation and redemption are much more closely linked by him. The life-giving and creative Spirit of God and the redemptive Spirit of Christ are similar (1992:9). The central category for appreciating the Spirit is life. Moltmann's (1992:34; see also 42) holistic pneumatology allows one to experience God "in, with and beneath each everyday experience of the world". The presence of God is experienced where life is affirmed. The Spirit is "the divine well-spring of life" (1992:82). The traditional ordo salutis is also aligned to this central concept of life (e.g., rebirth to life; sanctification of life). The same applies to the spirituality: A true spirituality "will be the restoration of the love for life" (1992:97).

A Trinitarian identification of the Spirit is generative of at least five critical insights. The Spirit is not only a mode of efficacy, but co-constitutive of the very life of God; "a second difference" is required, in Milbank's (1986:230) words, to establish the distinctive pluralist understanding of God's identity in the Christian imagination. Secondly, identity is construed in terms of relationality. The identity of Father, Son and Spirit, respectively, is established not in typical modernist fashion as autonomous self-constitution, but by the face of the Other. Selfhood carries with it connotation of ex-stasis, mutuality, reciprocity, donation, gift - ultimately of love. The Trinity is the grammar of this love. This moves thinking decisively beyond any vestige of modalism. Thirdly, any traditional truncation is reverted; the Spirit's identity is expanded in the relationship to both Father and Son, to both creation and redemption. This implies the dialectic of both universality ${ }^{31}$ and particularity. The Spirit is the power of life, but also the power of cross and resurrection of a contingent life. Fourthly, the Trinity furnishes a decisive hermeneutical lens. McDonnell's (1985:206) statement, "The Trinitarian mystery is the ultimate reality and the absolute hermeneutic", can be interpreted in various directions, not only for an entire theological vision, but also specifically for pneumatology; he also warns against a pneumatology "divorced from Trinitarian controls and principles" (1985:214). ${ }^{32}$ Finally, and for this article's argument most critical, a Trinitarian optic can integrate the other motifs. The love of the Triune Spirit is the white light that radiates the bright colours of novelty, emergence, justice, hospitality and beauty. The Spirit is the exuberant agency of the Father and the Son.

29 The position by the Dutch scholar Van de Beek in his new study on the Spirit (2012:393ff) represents an extreme opposite view, limiting the Spirit to Christ and the church. A careful analysis of his arguments is necessary. My impression is that his view should be understood in terms of his larger oeuvre, and especially his pessimistic assessment of secular culture. Pneumatologies are determined by strong theological currents. Interestingly, he distances himself from his earlier, more cosmically oriented work (1987).

30 The literature on the topic is vast. The recently published work by Emery and Levering (eds.), The Oxford handbook of the Trinity (2011), provides a virtual encyclopaedic state of current scholarship. It also includes a separate article on Trinitarian pneumatology.

31 Kasper (1983:202) makes the striking observation in terms of a universal perspective: The Holy Spirit "is concerned with life as such and with the meaning of all life, with the origin and goal of life, with the power that gives life."

32 In McDonnell's (1985:208ff) view, the Spirit is the "point of contact between God and humankind", and refers to the "link character" of pneumatology. 
The implication of the results of the previous and central part will be pointed out in this section. The underlying conviction has been throughout that better understanding of the nature of the Spirit's work may facilitate discernment. Consequently, the potential impact by the distilled motifs should be intimated.

a. The specific approach followed in this instance does not pretend to present either an exhaustive or even exclusive treatment. The strengths are, however, obvious: the discussion is located in contemporary concerns and debates, but also conveys some indication of the expanded appreciation of the Spirit's reach. The critical question, which can be directed to my approach and the results, is whether it can carry the burden of Christian Scriptural witness. It is virtually futile to attempt to typologise the numerous associations with Spirit in the Bible; they are too diverse to be reduced to singular and comprehensive categories. Certain motifs such as life, endowment for tasks, power, future, truth, and the link with Christ do recur and should be expressly noted,. Where these motifs cannot be integrated with my proposal, the limitation should be acknowledged, and additional motifs should be added. An interesting test case will be the traditional relation between Spirit and salvation. To determine where to group it will depend on what soteriological metaphor is preferred, e.g. righteousness or theosis will obviously show affinity to different linguistic connotations - one to justice, the other to relationality.

b. The question should be pondered as to whether an interdisciplinary conversation with other non-theological disciplines could offer valuable recourses for conceptualising the nature of the Spirit's work and action. This refers to the heuristic potential of theories of agency. In the manner that socio-scientific theories have benefited Biblical interpretation, similar theories from sociology, for instance, could enrich theological reflection. I consider this a promising area for future research.

c. The inherent expansiveness of the motifs identified should be recognised. Each motif elicits a range of semantic possibilities of related notions. For example, when reflecting on the Holy Spirit in terms of novelty, freedom comes to mind; of emergence - the future; of justice - reconciliation; of hospitality - otherness; of beauty-desire; of the Impossible - excess, and of relationality - vulnerability. A surplus of meaning is thus at play, and the possibilities should be creatively explored. A fundamental consideration with the deliberate selection of trends was to relocate the agency of the Spirit to a public world featuring numerous conflicts of interpretation. The expansiveness refers not only to linguistic notions, but also to social, anthropological and intellectual domains. The Spirit is present in a unique manner in our epistemologies, our politics, our art, our relations, and so on. Discernment is required in every sphere of life; ${ }^{33}$ our pneumatologies should correspondingly be spacious.

d. Each motif does not only encourage the articulation of associated notions, but also possesses structurally a counter motif which resists the very work of the Spirit. Basic to discernment is the old tradition of two ways (see Waaijman 2000:485ff). Every assertion

33 Buckley (1993:279) is worth quoting when he discusses the history of the tradition of discernment:

"Discernment ranged over the whole interpretative process in which human beings make decisions." 
about the character of the Spirit's work evokes a field of connotation which opposes that. For example, an inexhaustible reservoir of possibilities presents itself - reactionary forces of sameness militates against the novelty of the Spirit; stasis against emergence; violence against justice; hubristic narcissism against hospitality; disharmony against beauty; closure against the Impossible, and autonomy against relationality.

e. The question could be validly raised as to whether speaking about the Spirit does not require dialectical modes of thinking. How can thinking accommodate the dialectic of creation/recreation, of cross/resurrection? Should the very modes of conceptualisation not be informed by the very nature of Spirit? A strong tradition, for instance in Paul, Luther, and Bonhoeffer, connects cross/power, presence/absence. I consider this a genuine pneumatological problematic which warrants further reflection. For example, emergence connotes higher levels of complexity with chaos; community presupposes particularity and unity; love is vulnerable, and power is not coercive. Levison (2011:90) points to the "symbiosis of ecstasy and intellectual acuity", emphasising "In a remarkable way, ecstasy and restraint, spontaneity and study, coalesce in early Christianity". The very propium, the recognisable and unique identity of the work of the Spirit, may be found exactly here. That each motif requires dialectical qualification seems to me inevitable. The inability to think dialectically and the insistence on making univocal assertions may be at the basis of much theological polemic. The implications for discernment are obvious: it will require space for ambiguity and for irony as inherent part of life.

f. To move from the results of the pneumatological overview to an interaction with discernment penetrates arguably to the heart of the argument. Or, to put it differently: how do these motifs apply to discernment and assist in any way? Assuming that discernment is essentially a hermeneutical practice, these motifs do establish a lens, or to change metaphors, create a symbolic world within which decisions are to be made. It would strictly be possible to pursue an analytical application with each motif. However, these motifs operate in a somewhat integrative fashion to form a specific pneumatic "habit of the mind", a disposition towards the world and its challenges. Those who inhabit the world of the Spirit, who love by the logic of the Spirit, display a preference for an open, hospitable, just and dialogical world, and embrace acts of kenosis and celebration. This description can endlessly continue, but always the same colours will be used to paint this exuberant sphere of the Spirit.

g. The previous line of thought has evoked reference to Spirituality. Nurturing a habit of mind for living in the strange world of the Spirit is nothing but journeying with the Spirit to greater intimacy with Transcendence. Inevitably, the theological investigation into pneumatology should enquire after its impact on Spirituality. ${ }^{34}$ If love subsumes notions such as novelty, emergence, justice, hospitality, beauty, and the impossible, then the question as to whether the Spirit does not extend an invitation to participation ${ }^{35}$ in a

34 In an excellent and recent article, Shults (2008) follows exactly the same argumentative procedure. Having examined shifts in contemporary pneumatology, he raises the question of the "transformation of spiritual practices" (2008:284). He centres his discussion on three major shifts in pneumatology, i.e. matter, person and force. He concludes that these conceptual shifts facilitate "embodied, communal, and hopeful forms of holistic spirituality" (2008:284).

35 In Trinitarian discourse, the question as to whether imitation should not rather be replaced with participation is often debated. Especially those who are critical of social Trinitarianism do prefer this; see, 
Trinitarian fellowship becomes acute. If the ultimate mystery of the Spirit's identity is related to the Father and Jesus Christ, then the proposal for a Trinitarian Spirituality ${ }^{36}$ becomes an attractive possibility. Because the very life of the Triune Mystery is eternally fecund, ecstatic, glorious, generous, in short love, those lives who participate in this open fellowship become iconic of these very perfections. The Holy Spirit renders Christian discernment a Trinitarian virtue, a capacity to opt for justice against violence, for hospitality amidst alienation, and for beauty in an age of ugliness.

\section{CONCLUSION}

The article argued that it is indeed possible to identify marks to interpret the movement of the Holy Spirit. Elements of a grammar for speaking about the work of the Spirit, which are receptive to the sensibilities of contemporary reflection, have been suggested. Where there are whispers of novelty or increasing complexity in the physical world, or justice and hospitality in the sociopolitical sphere, or beauty in human imaginative expression, we may rightfully discern the work of the Spirit. The 'impossible' will prevent conceptual control of the Spirit: despite recognisable features of the presence of the Spirit, her movement will always remain incomprehensible and hidden. But, finally, the work will always relate to the Father and the Son. The idiom of the Spirit's language is recognisable as a movement of love in our challenging world. Where the beautiful melody of love is heard, the music of the Spirit is performed.

\section{BIBLIOGRAPHY}

Anderson, A 2004. An introduction to Pentecostalism. Cambridge: Cambridge University Press.

Anderson, A, Bergunder, M, Droogers, A \& Van der Laan, C (eds.) 2010. Studying global Pentecostalism:

Theories and methods. Berkeley, CA: University of California Press.

Baum, G (ed.) 1999. The twentieth century: A theological overview. Maryknoll, NY: Orbis.

Buckley, M J 1993. Discernment of spirits, in Downey, M (ed.) 1993:274-281.

Caputo, J D 2006. The weakness of God: A theology of the event. Bloomington, IN: Indiana University Press.

Caputo, J D \& Scanlon, M J (eds.) 1999. God, the gift and postmodernism. Bloomington, IN: Indiana University Press.

Clayton, P 2005. Theology and physical science, in Ford, D F (ed.) 2005:342-356.

Clayton, P \& Simpson, Z (eds.) 2006. The Oxford handbook of religion and science. Oxford: Oxford University Press.

Comblin, J 1989. The Holy Spirit and liberation. Maryknoll, NY: Orbis.

Cox, $\mathrm{H}$ 1999. The myth of the twentieth century: The rise and fall of 'secularization', in Baum, G (ed.) 1999:135-143.

Delattre, R A 1968 (2006). Beauty and sensibility in the thought of Jonathan Edwards. Eugene, OR: Wipf \& Stock.

Downey, M 2000. Altogether gift: A Trinitarian spirituality. Maryknoll, NY: Orbis.

Downey, M (ed.) 1993. The new dictionary of Catholic spirituality. Collegeville, MN: Liturgical Press.

Dyrness, W A 2007. The arts, in Webster, J, Tanner, K \& Torrance, I (eds.) 2007:561-579.

Ellis, G F R 2006. Physics, complexity and the science-religion debate, in Clayton \& Simpson 2006:751-766.

Emery, G \& Levering, M (eds.) 2011. The Oxford handbook to the Trinity. Oxford: Oxford University Press.

Endean, P 2005. Spirituality and theology, in Sheldrake 2005:74-79.

Farley, E 2001. Faith and beauty: A theological aesthetics. Aldershot: Ashgate.

Fiorenza, F S \& Galvin, J P (eds.) 2011. Systematic Theology: Roman Catholic perspectives. $2^{\text {nd }}$ ed.

Minneapolis, MN: Fortress.

e.g., Tanner (2012: esp. 382-386).

36 There is a growing literature on this subject. For a beautiful meditation, see Downey (2000) - Altogether gift: A Trinitarian spirituality. 
Firth, D G \& Wegner, P D (eds.) 2011. Presence, power and promise. Nottingham: Apollos (Inter Varsity).

Ford, D F 2011. The future of Christian theology. Oxford: Wiley-Blackwell.

Ford, D F (ed.) 2005. The modern theologians. $3^{\text {rd }}$ ed. Oxford: Blackwell.

Gregersen, N H 2006. Emergence and complexity, in Clayton \& Simpson 2006:767-783.

Haight, R 2008. Holy Spirit and the religions, in Jensen, D H (ed.) 2008:55-69.

Hess, R S 2011. Bezalel and Oholiab: Spirit and creativity, in Firth \& Wegner 2011:161-172.

Holder, A (ed.) 2005. The Blackwell companion to Christian spirituality. Oxford: Blackwell.

Jensen, D H (ed.) 2008. The Lord and Giver of Life: Perspectives on constructive pneumatology. Louisville, KY: Westminster John Knox.

Jones, S \& Lakeland, P (eds.) 2005. Constructive theology: A contemporary approach to classical themes. Minneapolis, MN: Fortress.

Kärkkäinen, V-M 2002. Pneumatology: The Holy Spirit in ecumenical, international and contextual perspective. Grand Rapids, MI: Baker.

---2004a. The working of the Spirit of God in creation and in the people of God: The pneumatology of Wolfhart Pannenberg. Pneuma 26(1):17-35.

--- 2004b. Trinity and religious pluralism. Aldershot: Ashgate.

Kasper, W 1983. The God of Jesus Christ. London: SCM.

Kearney, R 2001. The God who may be: A hermeneutics of religion. Bloomington, IN: Indiana University Press.

Levison, J R 2009. Filled with the Spirit. Grand Rapids, MI: Eerdmans.

---2011. Recommendations for the future of pneumatology. Pneuma 33:79-93.

Liebert, E 2008. The way of discernment: Spiritual practices for decision making. Louisville, KY: Westminster John Knox.

Lienhard, J T 1980. On 'discernment of spirits' in the early church. Theological Studies 41(3):505-528.

Lonsdale, D 2005a. The church as context for Christian spirituality, in Holder, A (ed.) 2005:239-253.

---2005b. Discernment, in Sheldrake, P (ed.), 2005:247-249.

Manoussakis, J P 2006. Introduction, in Manoussakis, J P (ed.) 2006:xv-xx.

Manoussakis, J P (ed.) 2006. After God: Richard Kearney and the religious turn in continental philosophy. New York: Fordham.

Marion, J-L 1991. God without being. Chicago, IL: University of Chicago Press.

McDonnell, K 1985. A Trinitarian theology of the Holy Spirit? Theological Studies 46:191-227.

Milbank, J 1986. The second difference: For a trinitarianism without reserve. Modern Theology 2(3):213234.

Mitchell, L J 2003. Jonathan Edwards on the experience of beauty. Studies in Reformed Theology and History no 9. Princeton, NJ: Princeton Theological Seminary.

Moltmann, J 1992. The Spirit of life: A universal affirmation. London: SCM.

Munzinger, A 2007. Discerning the Spirits: Theological and ethical hermeneutics in Paul. Cambridge: Cambridge University Press.

Newlands, G \& Smith, A 2010. Hospitable God: The transformative dream. Surrey: Ashgate.

Pannenberg, W 1994. Systematic theology, vol 2. Grand Rapids, MI: Eerdmans.

Plantinga, R J, Thompson, T R \& Lundberg, M D (eds.) 2010. An introduction to Christian theology.

Cambridge: Cambridge University Press.

Polkinghorne, J 2006. The hidden Spirit and the cosmos, in Welker 2006:169-182.

Russell, R J 2007. Five key topics on the frontier of theology and science today. Dialog 46(3):199-207.

Russell, R J, Murphy, N \& Stoeger, W R (eds.) 2008. Scientific perspectives on divine action: Twenty years of challenge and progress. Vatican City: Vatican Observatory Publ \& Berkeley: CTNS

Schrijvers, J 2006. On doing theology 'after' Ontotheology: Notes on a French debate. New Blackfriars 87:302-314.

Schweizer, E 1989. On distinguishing between spirits. Ecumenical Review 41(3):406-415.

Sheldrake, P 2005. The New Westminster dictionary of Christian spirituality. Louisville, KY: Westminster John Knox.

Sherry, P 2002. Spirit and beauty: An introduction to theological aesthetics. $2^{\text {nd }}$ ed. London: SCM.

---2007. The beauty of God the Holy Spirit. Theology Today 64:5-13.

Shults, F L 2008. Spirit and spirituality: Philosophical trends in late modern pneumatology. Pneuma 30:271287. 
Smith, J K A 2003. What hath Cambridge to do with Azusa Street? Radical Orthodoxy and Pentecostal theology in conversation. Pneuma 25(1):97-114.

---2008. Is the universe open for surprise? Pentecostal ontology and the spirit of naturalism. Zygon 43(4):879-896.

---2010. Thinking in tongues: Pentecostal contributions to Christian philosophy. Grand Rapids, MI: Eerdmans.

Smith, J K A \& Yong, A (eds.) 2010. Science and the Spirit: A Pentecostal engagement with the sciences. Bloomington, IN: Indiana University Press.

Tanner, K 2012. Social Trinitarianism and its critics, in Woźniak, R J \& Maspero, G (eds.) 2012:368-386.

Tracy, D 2011. Approaching the Christian understanding of God, in Fiorenza, F S \& Galvin, J P (eds.) 2011:109-129.

Van de Beek, A 1987. De adem van God: De Heilige Geest in kerk en kosmos. Nijkerk: Callenbach.

---2012. Lichaam en Geest van Christus: De theologie van de kerk en de Heilige Gees. Zoetermeer: Meinema.

Vondey, W 2009. The Holy Spirit and the physical universe: The impact of scientific paradigm shifts on contemporary pneumatology. Theological Studies 70:3-36.

Waaijman, K 2000. Spiritualiteit: Vormen, grondslagen, methoden. Kampen: Kok.

Webster, J 1983. The identity of the Holy Spirit: A problem in Trinitarian theology. Themelios 9(1):4-7.

Webster, J, Tanner, K \& Torrance, I (eds.) 2007. The Oxford handbook of systematic theology. Oxford: Oxford University Press.

Welker, M (ed.) 2006. The work of the Spirit: Pneumatology and pentecostalism. Grand Rapids, MI: Eerdmans.

Welker, M 1994. God the Spirit. Minneapolis, MN: Fortress.

---2007. The Holy Spirit, in Webster, J, Tanner, K \& Torrance, I (eds.) 2007:236-248.

Welker, M (ed.) 2012. The Spirit in creation and new creation: Science and theology in Western and Orthodox realms. Grand Rapids, MI: Eerdmans.

Woźniak, R J \& Maspero, G (eds.) 2012. Rethinking Trinitarian theology. London: T \& T Clark (Continuum).

Yong, A 2006. Ruach, the primordial chaos, and the breath of life: Emergence theory and the creation narratives in pneumatological perspective, in Welker 2006:183-204.

---2007. The Spirit of hospitality: Pentecostal perspectives towards a performative theology of interreligious encounter. Missiology: An International Review 35(1):55-73.

---2008. Hospitality and the Other: Pentecost, Christian practices, and the neighbor. Maryknoll, NY: Orbis.

---2010. In the days of Caesar: Pentecostalism and political theology. Grand Rapids, MI: Eerdmans.

---2011. The Spirit of creation: Modern science and divine action in the Pentecostal-Charismatic imagination. Grand Rapids, MI: Eerdmans.

\section{KEY WORDS}

Discernment

Holy Spirit

Hospitality

(The) Impossible

Pneumatic agency

Relationality

Spirituality

\section{TREFWOORDE}

Onderskeiding

Gasvryheid

Geestelike handeling

Heilige Gees

(Die) Onmoontlike

Relasionaliteit

Spiritualiteit
Prof. Rian Venter

Faculty of Theology

Department of Systematic

Theology

University of the Free State

P O Box 339

BLOEMFONTEIN 9300

Tel: 0722095956

E-mail: rianventer@mweb.co.za 